\title{
Intrastate Conflict and International Peacekeeping Operations in the Central African Republic (CAR)
}

\author{
Ibrahim Abdullahi \\ Director, Khalil Integrated Academy (KHIA), Nigeria
}

\begin{abstract}
The Post-Cold war world politics witnessed a dramatic shift, while proxy wars and interstate conflicts peculiar to the Cold war era significantly declined, an intense trend of intrastate conflict began to manifest. The gruesome and atrocious nature of such violence with its concomitant trans-border effects attracted intervention from the international communities with intention of rescuing civilians and restoring peace and order. Records of successive peacekeeping interventions has shown that approaches are rather curative, which are geared towards a mere violence mitigation than a holistic conflict prevention mechanism. Despite massive troop deployment by the international community in the Central African Republic CAR, widespread and grave violation of human rights is not halted, leading to further escalations and the entanglement of the mission in the conflict. Most studies on humanitarian intervention focused largely on post-conflict intervention and this study attempts to critique this post-cold war posture and argue for a humanitarian intervention based on conflict prevention. The failure of the international community to stop the humanitarian crisis in the CAR underscores the need for this study on conflict prevention. Secondary data is adopted in the course of this study, using descriptive method of analysis to measure intensity of violence and the impact of the international peacekeeping operations in containing the conflict situation in the CAR.The following finding and recommendations are made: International actors predominantly share a pessimistic view of CAR, coupled with a general lack of commitment in the conflict and misunderstanding of the country's internal dynamics. This perception shapes the type of engagement privileged by the international community in the CAR, which is mainly reactive in nature and designed to simply stabilize the country for the sake of regional affairs that are deemed to be of greater importance. The dominant reactive nature of the engagement in CAR produces an unsuccessful response, hence the need to reach an effective conflict prevention approach; International interventions in the CAR should be reoriented towards addressing state governance and the drivers of violence.
\end{abstract}

Keywords: Post-Cold War, Intrastate Conflict, International Peacekeeping Operations, Central African Republic, International Community

\section{INTRODUCTION}

\subsection{Background to the Study}

$\mathrm{T}$ he end of the Cold War witnessed a significant change in international relations. Scholars describe the immediate post-Cold War period as "golden era" for humanitarian activism or "decade of humanitarian intervention" (Guraziu, 2008). Weiss (2004) argues that human beings matter more than sovereignty across the international political horizon of the 1990s. There is no doubt that during the 1990s, states began to contemplate intervention to protect imperilled strangers in distant land (Bellamy and Wheeler, 2005). While the proxy wars and inter-state conflicts considerably declined, a dramatic shift from inter-state to an increasingly intra-state conflict began to manifest. The world since then has become racked by ethnic and nationalist violence. The tragedies and gruesome atrocities concomitant with these eruptions have pushed the imperative for humanitarian intervention to the fore of contemporary international politics and practice, provoking a shift on the international right and necessity of using military force to protect civilians within sovereign states (Bontwell and Klare, 2000: Weiss, 2004: Enuka, 2012).

The end of the cold war has been characterized by a wave of violent civil wars and armed conflicts in Africa that have produced unprecedented humanitarian catastrophe and sufferings. Although mostly intra-state, these conflicts have spread across borders and threatened international peace and security through mass refugee flow, proliferation of small arms and light weapons and the rise of local mercenary groups (Bontwell and Klare, 2000). Since the end of cold war, from the Balkans to East-Timor, and throughout Africa, the world has witnessed an outbreak of ethnic, religious, and sectarian conflicts characterized by routine massacre of civilians. Terminologies to describe such conflict include "Protracted social conflict" or "Complex political emergencies" (Azar, 1990: Kaldor, 2001) which involve a blurring of organized crimes and large-scale violations of human rights, vicious civil wars sustained by identity politics, supported by diasporas and waged by paramilitary gangs (Smith, 2003), interpreted as new barbarism and a return to medieval forms of tribal war and warlordism (Francis, 2000). Despite their seemingly internal nature, they have regional and international dimensions and ramifications. These were seen in Somalia, Rwanda, Congo Democratic Republic, Darfur in Sudan, Liberia, Sierra Leone, and more recently in Libya and Mali, and currently in Egypt, South Sudan, Kenya, Nigeria, among others.

International Peacekeeping Operation is prominent in the maintenance and restoration of international peace and security where violence occurs (Walzer, 2000); it is aimed at preventing widespread and grave violations of the fundamental human rights (Holzrefe and Keohane, 2003). However, humanitarian intervention is prone to abuse as it provides cover for self-interested actions (Annan, 1999), because interveners use issues regarding human rights as a 
pretext for intervention in order to achieve their political objectives (Brownlie, 1998). Interveners still find that they become embroiled in an unending commitment (Luttwak, 1999).

However, successive international peace missions in Africa fail to stem or halt widespread and grave violation of human rights and genocides, either as a result of incompetence, lack of effective mechanism or of their inability to understand the dynamics of African conflict. In Central Africa despite the presence of international troops that have the mandate of stemming the killings and grave humanitarian sufferings, the situation is continuously taking an ugly dimension which has elevated the crisis to ethnic cleansing and genocide. The international response to the conflict has seemingly been unable to halt the violence and the forces are unable or unwilling to confront the militias (Amnesty International, 2014: Ero, 2014: Henquinet, 2014: Rovera, 2014).

\subsection{Statement of the Problem}

Violence in the Central African Republic (CAR) has intensified ever since the coup d'état in early March 2013 which sent the nation into wholesale unrest that proceeded to take a sectarian turn thereafter (Henquinet, 2014). Situations worsened and matters deteriorated at a much faster pace than the international response is mobilizing, the international humanitarian response seemingly failed to halt the violence, the African Union Peacekeeping forces and the French military support have been unable to comprehend and contain the dynamics and complexities of the Central African Republic's intra-state crisis, leading to the total breakdown of law and order, human right abuses and the killings of tens of hundreds that led to ethnic cleansing and genocide accusations, while thousands were displaced and forced out. As of mid-January 2014, some 900,000 residents (nearly one in five) were internally displaced, while another 86,000 had fled to neighbouring countries as refugees. U.N. agencies estimated that 2.6 million people, or half of the population, require humanitarian aid, and that $60 \%$ of households have no available food stocks, all these happening amidst the intervening troops (USAID, 2014: Arieff, 2014). Most studies on humanitarian intervention focused largely on post-conflict intervention and this study attempts to critique this post-cold war posture and argue for a humanitarian intervention based on conflict prevention (preventive than curative). The failure of the international community to stop the humanitarian crisis in the CAR underscores the need for a study on conflict prevention.

\subsection{Objectives of the Study}

The general objective of this study is to examine the international peacekeeping operations in the Central African Republic (CAR). The specific objectives are to:

i. Assess the nature of the international peacekeeping in the Post-Cold war intrastate conflict in African. ii. Explore the nature and dynamics of the conflicts in the CAR

iii. Evaluate the effect of the international peace support mission in containing the conflict situation in the Central African Republic CAR.

\subsection{Research Questions}

i. What is the nature of international peacekeeping in the Post-Cold war intra-state conflict in Africa?

ii. What is the nature and dynamics of the conflict in the CAR?

iii. What effect has the international peacekeeping mission made in containing the conflict in the CAR?

\subsection{Significance of the Study}

The significance of this study is that it added to the existing literature a new perspective in understanding the nature, dynamics and complexities of peacekeeping operations on contemporary conflicts in Africa. The study exposesto the diplomatic community, international decision makers and the academia the effectiveness of international responses in containing conflict situations in African. It is also be of significance to policy reviews in informing the propositioning of better and effective preventive approach and more importantly it added to knowledge and practice.

\subsection{Methodology}

Qualitative method is adopted in this study and Descriptive method is used in obtaining information on the current status and in describing "what exists" with respect to the situation in the CAR. Data for this study is generated through content analysis, basically through desk review approach, by collating and analysing information on the subject matter from Reports of international humanitarian organizations and research agencies, Textbooks, e-books, Scholarly Researches and Publications, Newspapers and Magazines, e-journals and Journal Articles, Seminar Papers and the Internet. The study had largely employed data projects like Armed Conflict Location and Database (ACLED), Uppsala Conflict Data Program (UCDP), Heidelberg Conflict Barometer (HCB), Global Conflict Trend (GCT), African Security Brief (ASB) and Congressional Research Service (CRS).

In contextualizing this study, the research analyses violence trend and intensity from the frequency of violent events and fatality rate. Impact of the peacekeeping operation is measured from the mitigations recorded in the violence frequency resulting from the peacekeeping operation. Effectiveness of the peacekeeping mission in the conflict is measured from the level of positive changes obtained, following the troop deployment.

\subsection{Scope of the Study}

This study is confined to examine the nature, trend, dynamics and the complexities of the conflict and sectarian violence that ensued March 2013 coup in the Central African Republic $(\mathrm{CAR})$, and the impact of subsequent international 
humanitarian response in containing the conflict. Data on the nature, intensity and complexity of the conflict in the CAR as well as the effect of the international peacekeeping mission on the conflict is collated from data projects of the following agencies: Armed Conflict Location and Data Project/Database (ACLED), Uppsala Conflict Data Program (UCDP), Heidelberg Conflict Barometer (HCB), Global Conflict Trend (GCT), African Security Brief (ASB) and Congressional Research Service (CRS).

\subsection{Definition of terms}

Cold war-is a conflict between nations that act with hostility toward one another but do not engage in direct warfare. The protracted cold war (1945-91) between the non-Communist and Communist countries, especially between the U.S. and the Soviet Union, in which each side attempted to check the global power and influence of the other. Cold War was characterized by a build-up of large military forces and nuclear arsenals, military interventions as in Asia and Africa, the use of propaganda and espionage. The period of hostility short of open war between the Soviet Bloc and the Western powers, especially the United States, 1945-9. In a nutshell, Cold war refers to an intense political, military, and ideological rivalry between nations, short of armed conflict.

Post-cold war- The period after intense political, military, and ideological rivalry between nations and their respective allies which resulted in a significant change in the world politics, culminating in unipolar system and new world order.

Actors-are entities which have the following three features: (a) They should have the autonomous capacity to determine their own purposes and interests; (b) They should also have the capability to mobilize human and material resources to achieve these purposes and interests; (c) Their actions should be significant enough to influence the state-to-state relations or the behavior of other non-state actors in the global system.

Inter-state conflict- Interstate violence is a conflict between two or more states (both members of the international system), who use their respective national forces in the conflict.

Intra-state conflict - Intrastate violence is the most common form of conflict today. It describes sustained political violence that takes place between armed groups representing the state, and one or more non-state groups. Violence of this sort usually is confined within the borders of a single state, but usually has significant international dimensions and holds the risk of spilling over into bordering states (the current conflict in Syria would be described as anintrastate conflict).

Peacekeeping- Military operations undertaken with the consent of all major parties to a dispute, designed to monitor and facilitate implementation of an agreement (ceasefire, truce, or other such agreement) and support diplomatic efforts to reach a long-term political settlement.

\section{LITERATURE REVIEW AND THEORETICAL FRAMEWORK}

\subsubsection{Central African Republic's Conflict and Intervention by International Community}

The conflict in the Central African Republic resulted into a brutal, circle of violence (BBC News, 17 January 2014). Previous issues of the Conflict Trends have described substantial increase and shifts in the dynamics of the violence in the Central African Republic throughout the year 2013. Conflict events increased in late 2013 and into January 2014, and levels of reported fatalities also reflected a general upward trend following a series of reprisal clashes between Seleka and anti-Balaka militia in Bangui in early December 2013 (ACLED, 2014: BBC News, January 2014). Security situation in the Central African Republic (CAR) has never been optimal, the country has struggled with recurrent insurgencies and army mutinies since the late 1990s (Better World Campaign, 2014).

In 2012, several primarily Muslim-led rebel groups formed a coalition called "Seleka" ("alliance" in the local lingua franca, Sango). In March 2013, Seleka rebels backed by France seized control of the government, deposing President Francois Bozize. Once in power, Seleka led by its former leader Michel Djotadia presided over the collapse of an already fragile state and oversaw brutal attacks on rural Christian communities in the North-west, Bozize's home region, leading to a widespread sectarian violence. Seleka fighters also targeted perceived Bozizé supporters in Bangui, including members of the national security forces. Pressures from neighbouring Central African states, the French and the lager international community prompted Djotadia's resignation and subsequent exile earlier in 2014. Following his departure, CAR's transitional governing authority appointed Catherine SambaPanza to serve as interim President until national elections to be held in February 2015 (Arieff, 2014: International Crisis Group, 2014).

However, the problem further metamorphosed into another phase of conflict, with the Western and Central regions, descending into sectarian violence. The atrocities committed by Seleka militia outraged the population and led to the creation of self-defence group called "anti-balaka", which means "anti-machete" in Sango language. These groups have been quick to target Muslim families and orchestrate what the Archbishop of Bangui described as a "return match". The antibalaka group appears to be led by former military officers, who display relatively sophisticated capacities, and have called for reinstating former president Bozize (an evangelical Christian). This has contributed to the perceptions that Bozize may be supporting them from exile (Marchal, 2013), hence, the further escalation of the conflict in September 2013. Seleka militia are slightly involved than anti-balaka and various communal militia, like the Mbarara, Mbororo, Fulani, Christian, and other similar groups), who were involved in a significant level of violence against civilians, reflecting the 
complexity of the religious dimensions of the conflict (ACLED, 2014). The violence in the CAR reflects a localized, urban-centred conflict, with by far the greatest number of conflict events taking place in Bangui (Amnesty International, 2013: HRW, 2013: Arieff, 2014). The significance of this increasing violence, with corresponding increase in human rights abuses, is reflected by the International Criminal Court's decision, on February 7, 2014, to launch a preliminary investigation into the violence in the Central African Republic, in response to allegations of mass killings, sexual violence, destruction of property and pillaging, forced displacement, and the use of child combatants, on the part of various armed groups (ICC, 2014: ACLED, 2014).

Prior to the crisis, CAR's population of 5.2 million was estimated to be $15 \%$ Muslim, $85 \%$ Christian and followers of indigenous beliefs (CIA World Factbook, 2014: UNOCHA, 2014), religious identity is often closely associated with ethnic identity. In recent times, amid widespread anti-balaka attacks, tens of thousands of Muslims have fled their homes. Muslimowned properties and businesses have been looted and seized and mosques have been destroyed. The United Nations (UN) Secretary General reported in March 2014 that "the ethnic and religious demography of the country has changed radically," with many areas "emptied" of their Muslim populations (UN, 2014).

Seleka has re-grouped, now led by Joseph Zindeko, a resident from the North-east region and one of the original leaders. There is still little to report about the aims of the group and its leaders. It has always been a mix of fragmented and competing opposition interests. The new grouping Organization of Central Muslim Resistance, established in late March 2014, claiming to have 5000 armed men, gleaned from former President Djotodia's former rebel group Union of Democratic Forces for Unity, Movement of Freedom Fighters of Central Africa for Justice and the Islamic Youth Organization. The first was a member of the Seleka Union while Djotodia ran the group, the recent histories of the second and third organizations are not known (International Crisis Group, 2014).

Religious ideology was not the origin of the crisis, which appears to reflect a complex struggle over access to resources and national identity. Indeed, many CAR religious leaders have sought to calm tensions, often at great personal risk. However, overlapping and often localized sources of tension and mutual fears have coalesced into mass violence, and many residents saw themselves locked in an existential battle along ethno-religious lines (Arieff, 2014: International Crisis Group, 2014: Better World Campaign, 2014).

According to the United Nations over 2,000 civilians have already been killed as of February, 2014 (ACLED, 2014: Better World Campaign, 2014: Dockings, 2014) over 100,000 residents have fled CAR since December 2013, bringing the total number of CAR refugees in neighbouring countries to about 350,000 as of April 2014 (UNHCR, 2014, UNOCHA,
2014). Some 600,000 more people are internally displaced within CAR. The U.N. High Commissioner for Refugees (UNHCR) has stated that the situation in CAR is outpacing the agency's capacity to provide assistance. Some 2.5 million people in CAR, or at least half the population, are thought to need humanitarian aid. Humanitarian conditions prior to the current crisis were already poor due to past conflicts and a lack of basic social services. Rising violence since 2012 including attacks on aid workers has further constrained humanitarian access. Separate in origin from the current crisis, the Lord's Resistance Army (LRA), a militia of Ugandan origin, continued to attack civilians in Southeast CAR, creating additional humanitarian needs (UN News Service, April 2014).

Economic impacts from prolonged violence could reverberate throughout the region, affecting neighbouring countries, which already face political and ethnic violence and economic instability of their own. Cameroon's northern territory has become a vortex for arms traffickers smuggling in weapons to CAR and South Sudan. Also, UN officials reported that Boko Haram, the militant Islamist group originating in Nigeria, already has a presence in the CAR, as well as in neighboring countries of Cameroon and Chad. As the U.S., UN, and the international community monitor the movement of this and other extremist groups in the region, an ungoverned CAR could become a future safe haven for terrorism and other illicit activities (Ira, 2013).

The situation in the CAR had drawn international concern, the U.N. Security Council Resolution 2127, adopted on December 5, 2013, authorized the French military, which has long had a presence in CAR, and an African Union (AU) operation, the African-led International Support Mission for CAR (MISCA), to protect civilians, enable humanitarian access, support the disarmament of militias, and contribute to security sector reform. About 2,000 troops from France, the former colonial power and some 6,000 MISCA soldiers and police have conducted operations under this authorization. The European Union has also pledged to send up to 1,000 troops to secure the airport (thereby relieving French forces), but they have been slow to deploy. On April 10, 2014, deeply concerned about the deteriorating security situation and human rights abuses in the Central African Republic (CAR), the Security Council approved the establishment of a nearly 12,000 strong United Nations Peacekeeping Operation, comprising up to 10,000 troops, 1,820 police, and a sizable civilian component, to protect civilians and facilitate humanitarian access in the war-torn country. Multidimensional Integrated Stabilization Mission in the Central African Republic (MINUSCA) is authorized by the U.N. Security Council Resolution 2149, which took off September 15, 2014, subsuming MISCA and a U.N. political mission (Arieff, 2014: UN, 2014: UN News Service, April 2014). Further, the Council requested UN Secretary-General Ban Ki-moon to incorporate the presence of the UN Integrated Peace Building Office in the Central 
African Republic (BINUCA) into MINUSCA as to ensure "a seamless transition" from one entity to the other.

On a diplomatic move, the Forum for National Reconciliation and Political Dialogue, tagged Brazzaville Forum, led by the Congolese president Denis Sassou Nguesso, on July 23, 2014, succeeded in getting the warring parties (Seleka and antibalaka) into signing a cease fire deal. The agreement symbolized end of the hostilities and was expected to allow free movement of goods and people in order to continue negotiations which led to disarmament and national

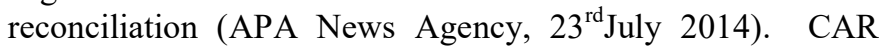
president Catherine Samba Panza was optimistic about the implementation of the agreement that it would end the humanitarian catastrophe in the country. The high command of the former ruling militia thereafter rejected the accord, claiming that those who sign the deal for his militia were not mandated to do so. General Joseph Zoundeko, the Chief of Staff of the Seleka faction based in Bambari, however pledge Seleka's readiness to continue the dialogue. While this was happening, killings and communal clashes still continued in some areas (All Africa, 2014). Soon thereafter, the Amnesty International in its November 6, 2014 report questioned the credibility of the UN forces amid rising attacks against civilians:

Serious human rights abuses are being committed in the Central African Republic (CAR), including killings, mutilation of bodies, abductions, and forced displacement. The United Nations Multidimensional Integrated Stabilization Mission in the Central African Republic (MINUSCA), deployed on 15 September 2014, has not yet been able to stop or prevent most of these abuses. Those responsible, including members of the Seleka, Anti-balaka, and their allies continue to enjoy impunity (Amnesty International, November 6, 2014).

Violence continued in many areas of the Central African Republic despite the deployment of the United Nations Multidimensional Integrated Stabilization Mission in the Central African Republic (MINUSCA), and the presence of French forces (known as Sangaris) and European Union forces (EUFOR). Although international forces have been crucial in reducing the level of violence and saving lives, deadly attacks by the Seleka, armed Peulhs, and Anti-balaka continue, including attacks against unarmed civilians at internally displaced people's camps.

According to UNHCR, the October 2014 wave of violence displaced some 6,500 people in Bangui alone, but that number could be much higher. In all, there are currently some 410,000 internally displaced people in the country, including over 60,000 in 34 sites in Bangui. Around 420,000 CAR refugees had fled to neighbouring countries.

\subsubsection{Central African Republic's Transition, Actors Convergence and Resurgence of Violence}

MINUSCA report (S/PV.7329) indicted that since 2014, there have been gross human rights violations and a resurgence of violence perpetrated by the anti-balaka, the Seleka and other groups. International Commission of Inquiry on the Central African Republic was established by resolution 2127 to investigate violations of international humanitarian law, international human rights law and abuses of human rights in the CAR. The Council adopted resolution 2196 renewing the CAR sanctions regime (arms embargo, assets freeze and travel ban) until 29 January 2016 and the mandate of the Panel of Experts assisting the 2127 CAR Sanctions Committee until 29 February 2016.

The CAR visit assessed progress and challenges facing MINUSCA and gave Council members an opportunity to meet with the transitional authorities on the political process, including preparations for elections. In addition to their activities in Bangui, Council members went to Bria in eastern CAR to visit local authorities, civil society and ex-Seleka members. On 12 March 2015, the Council held its Ninth Annual Joint Consultative Session Meeting with the AU Peace and Security Council. Following an additional week of negotiations, a communiqué on the joint session was issued. Subsequently, Council members issued a press statement welcoming the holding of the Bangui forum on national reconciliation from 4 to 11 May 2015 (SC/11895). Council members commended the adoption of the Republican Pact for Peace, National Reconciliation and Reconstruction, including commitments for a swift presidential and legislative electoral process.

Resolution 2281 extended MINUSCA's mandate until $31^{\text {st }}$ July 2016 and requested the Secretary-General to conduct a strategic review of its mandate by $22^{\text {nd }}$ June. Council members issued a press statement on $18^{\text {th }}$ April 2016 condemning the killing of a MINUSCA peacekeeper(Chronology of Events Security Council, August 2020).

The transitional period from 2014 to 2016 allowed for a degree of calm, the establishment of an inclusive peace process and for national elections to be held in February 2016. The elections were considered to have been transparent and conducted in a peaceful manner. Faustin-Archange Touadera, a former prime minister and maths professor, was declared the winner of a presidential election in February 2016 seen as crucial to turning the page on years of sectarian violence. $\mathrm{Mr}$ Touadera won $62.71 \%$ of the hotly contested run-off vote compared with 37.29 for Anicet-Georges Dologuele, who won the first round of the vote in December and conceded defeat in the second (BBC 2018).

President Faustin Archange Touadera delivered a speech to the nation during his inauguration on 30 March 2016, instituting his key priorities and principles: the establishment of security, justice, and a reconciliation process. His government would go on to sign the Agreement for Peace and Reconciliation in the Central African Republic (APPRRCA) with 14 armed groups on 6 February 2019. Under this accord, the armed groups agreed to a cessation of hostilities in exchange for the inclusion of representatives in the 
institutions of the republic. The parties further reached an agreement on the parameters of a judicial and reconciliation process, the establishment of mixed security units and the participation of irregular combatants in a process of demobilisation and reintegration. Nevertheless, as different parties to the conflict continue to fragment, the implementation of the APPR-RCA requires an ongoing mechanism for dialogue to adapt to new developments (Times, $5^{\text {th }}$ April 2016). Touadera's task was enormous, and he will need foreign diplomatic and financial support. A 2015 U.N. commission of inquiry report found that as many as 6,000 people may have been killed over the past three years of fighting. About 900,000 people are displaced from their home and 2.1 million people-nearly half the total population-are facing hunger. But Touadera cannot simply turn to donors for help. In order to stabilize the country and restart the economy, he will need to lead the way, setting an agenda to address three major threats: corruption, impunity and the pillage. Special Criminal Court was immediately establishedwith the potential to end decades of impunity in CAR, but the government was to cooperate fully with international stakeholders, safeguard the court's independence and ensure that cases address crimes committed by all sides. Foreign governments and donors should support the court with financial assistance and expertise.President Touadera's focus was on foundational actions for reconstruction and to reconcile people through a process of seeking truth and justice.

The path to peace came about through dialogue between the Central African Republic and the armed groups that saw the light during talks that took place under the aegis of the African Union. Touadera left no doubt that his impoverished, mineral-rich nation faces enormous challenges to ending violence that began in 2012 when anti-government militias spurred by perceptions of economic and political exclusion and the government's failure to implement a 2008 agreement, organized and later seized the capital. The Central African Republic has turned its back on past dark days," he told Assembly's annual general debate, emphasizing the country's efforts to end the cycles of violence and instability sparked by a 2013 coup, and to attain security, justice and sustainable development. "Despite our progress, the situation is a fragile one," he said, noting that he had taken a special interest in bringing the entire country together under a fourstage framework based on peace and security; national reconciliation; economic recovery; and justice and human rights. Measures proceeding along these lines will help the country ward off the perils of poverty and insecurity, he said, noting that he will also make a special appeal at the upcoming November Brussels conference on his country to assist with rebuilding and strengthening institutions (UN News, 2016: Africa Renewal)

Nevertheless, the transition did little to resolve underlying structural problems. The fragility of the state apparatus, which continues to struggle to impose its authority outsideof the capital of Bangui; a lack of adequate infrastructure; rampant corruption and poverty; and porous borders, continue to threaten the stability of CAR (Centre for Humanitarian Dialogue, 2016).

Violence in eastern and western Central African Republic (CAR) has increased and spread to new provinces in 2018, as the government in Bangui remains unable to extend control outside the capital. A peace agreement signed in June 2017 between the government and thirteen of the fourteen main armed factions had little effect, and ex-Seleka and anti-balaka militias along with hundreds of other localized groups operate openly and control as much as two-thirds of CAR's territory(Council For Foreign Relations, November 2020). In April 2018, the UN Multidimensional Integrated Stabilization Mission in the Central African Republic (MINUSCA) and government security forces launched an operation to disarm a militia group in Bangui's PK5 neighbourhood, a predominantly Muslim enclave in the majority Christian city. After rumours spread that the peacekeepers intended to disarm all Muslims, leaving them vulnerable to attacks by armed Christian groups, heavy clashes broke out, killing more than twenty people, including a UN peacekeeper, and wounding nearly one hundred fifty. Days later, demonstrators laid the bodies of sixteen people killed in the violence in front of MINUSCA's headquarters in Bangui, accusing peacekeepers of firing on civilians.

Over the following weeks, violence spread outside of PK5 as reprisal attacks were carried out by both ex-Seleka and antibalaka militias. In May 2018, gunmen attacked a church in Bangui, killing sixteen people including a priest; several mosques were attacked in retaliation. Ex-Seleka leaders met in northern CAR and threatened to attack the capital, prompting MINUSCA to enhance security around the city(Council For Foreign Relations, November 2020).

"My country became a cliche of hate that might be considered almost predictable between Christians and Muslims," Touadera said. Except, he added, religious strife had little to do with the conflict at the outset. The religious dimension came later as Christian militias (anti-Balaka) organized against the Muslim Seleka coalition that took power by a coup in 2013, leading to violence against citizens on the basis of their religion." (Touadera April 2019, UN Institute of Peace).

Despite optimism after the election of President Faustin Archange Touadera in the spring of 2016, the crisis only intensified. A de facto territorial partition led to a pause in Muslim-Christian fighting, but fighting between factions of the ex-Seleka has grown. Though the government maintains control of Bangui, most armed groups have boycotted President Touadera's attempts to calm the region through disarmament, leaving the government powerless outside the capital. Lawlessness in the rest of the country has allowed armed groups to thrive and fighting has increased in the central, western, and eastern provinces. The conflict has also 
wreaked havoc on the economy, crippling the private sector and leaving nearly 75 percent of the country's population in poverty (Council For Foreign Relations, November 2020).

\subsubsection{Theoretical Framework}

Conflict system and Conflict Transformation theories are applied in the course of this study; Transformation proposition is adopted for clarity and better understanding.

\subsubsection{Conflict Transformation Theory}

Conflict transformation refers to the process of moving from conflict-habituated systems to peace systems. This process is distinguished from the more common term of conflict resolution because of its focus on systems change. Social conflicts that are deep-rooted or intractable get these names because the conflict has created patterns that have become part of the social system. With the social system as the unit of analysis, the term "resolution" becomes less appropriate. Transforming deep-rooted conflicts is only partly about "resolving" the issues of the conflict - the central issue is systemic change or transformation. Systems cannot be "resolved," but they can be transformed.

Transformationalists see this concept as an improvement over conflict resolution because conflict resolution supposedly "resolves" the conflict but ultimately sets the parties up for failure. The argument, of course, is that it leaves the system within which the conflict occurs, or the underlying causes of the conflict, untouched. In that sense, conflict transformation has social change as its ultimate purpose. Furthermore, in contrasts conflict resolution as a theory and process that leads to a practical end-state with the more open-ended, and indeed continuous, conflict transformation process. A number of theorists have alluded to the idea of conflict transformation as an ongoing, never-ending process (Galtung, 1996; Raimo, 1991; Lederach, 1997), and as a way to create "new social relations, institutions, and visions" (Raimo 1999).

Conflict transformation occurs when there is a metamorphosis, or at least considerable change, in one of three different elements. The process of transformation first transforms attitudes by changing and redirecting negative perceptions. Secondly, it transforms behaviour, and lastly, transforms the conflict itself by seeking to discover, define, and remove incompatibilities between the parties.

Four ways in which transformations happen:

Actor Transformation refers to the internal changes in major parties to the conflict, or the appearance of new actors.

- Issue Transformation alters the political agenda of the conflict altering what the conflict is about.

- Rule Transformation redefines the norms that the actors follow in their interactions with each other and demarcates the boundaries of their relationship.

- Structural Transformation alludes to changes that may transpire in the system or structure within which the conflict occurs, which is more than just the limited changes among actors, issues and roles.

\section{DATA PRESENTATION AND ANALYSIS}

Data on the nature, intensity and complexity of the conflict in the CAR as well as the impact of the international peace support mission on the conflict and the effectiveness of peacekeeping operations is collated from data projects of the following agencies: Armed Conflict Location and Data Project/Database (ACLED), Uppsala Conflict Data Programme (UCDP), Heidelberg Conflict Barometer (HCB), Global Conflict Trend (GCT), African Security Brief (ASB) and Congressional Research Service (CRS).

\subsection{Results and Discussion}

Fig. 1 Violent Events by Type, Cental African Republic, January 2010 August 2014

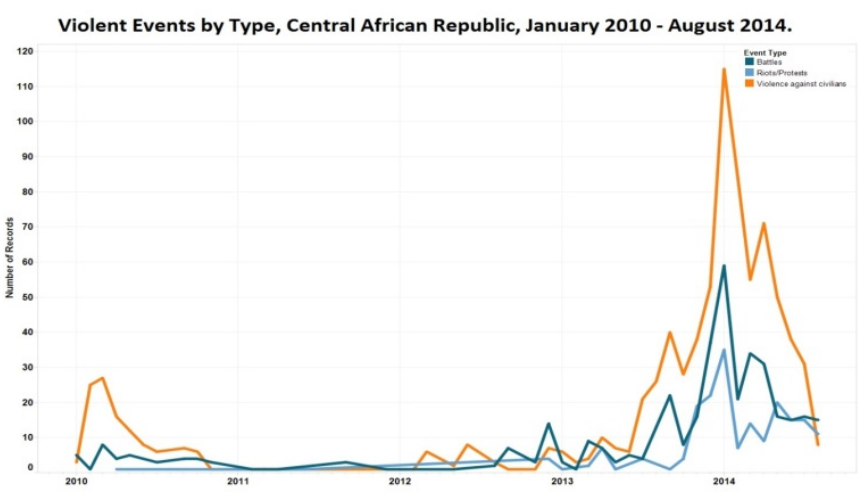

(ACLED, September 2014)

Violence against unarmed civilian in the CAR ranging from killings, mutilation of body, kidnapping, sexual crimes and forced displacement increased in frequencyfrom 10\% in 2013 and radically intensified to $120 \%$ through the first quarter of 2014 , subsequently violence frequency significantly dropped to less than $10 \%$, as it could be observed from figure 1 . This is not unconnected with the increased in the robustness of the peacekeeping operation.

Fig. 2: Conflict Events by Actor, by Month, Central African Republic January 2013 - May 2014.

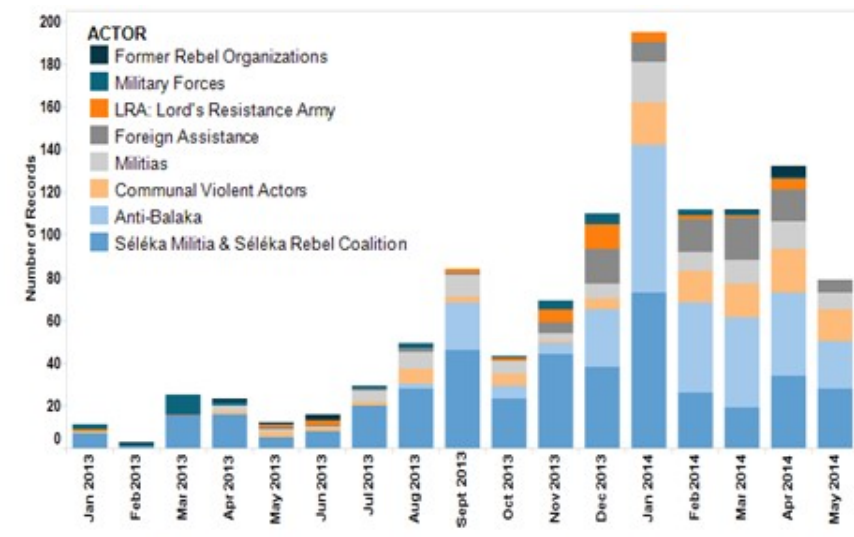

(ACLED, June 2014:Heidelberg Conflict Barometer (HCB), 2014) 
Figure 2 shows actors that are involved in the Central African Republic's conflict and their level of involvement. Seleka Militia and Seleka Rebel Coalition, Anti-Balaka and Communal Violent Actors had the largest involvement in the Central African Republic's conflict. Militias, Foreign Assistance, the Lord's Resistance Army LRA, National Forces and Former Rebel Groups are other actors that were also involved on the periphery of the conflict. In March, 2013 on the eruption of the violence, the Seleka and Former Rebel Organization have dominated the conflict, from April August 2013 Seleka led with about $70 \%$ involvement in the conflict, with the other actors' little involvement of $20-25 \%$ in the shadow of the violence, September - November 2013 there was an escalation in the conflict, Seleka leading the involvement and other actors particularly the anti-balaka have grown in their involvement in the conflict in about $30 \%$, December 2013 - January 2014 the escalation in the conflict got to its peak, Seleka still leading the involvement in the conflict and anti-balaka was growing more in its involvement, February - March 2014 the violence was de-escalating and anti-balaka was taking the lead of $60 \%$ involvement prompted by Djotodi's resignation and dismantling of Seleka forces, April - May 2014 Anti-balaka and Seleka's involvement was in an equal proportion resulting from Seleka's re-grouping and new leadership. Between January and May 2014 other actors, particularly Communal Violent Actors, Militias, Foreign Assistance and Former Rebel Organization relatively grew in their level of involvement in the conflict.

Fig. 3: Conflict Events by Type, Central African Republic, January 2013 January 2014.

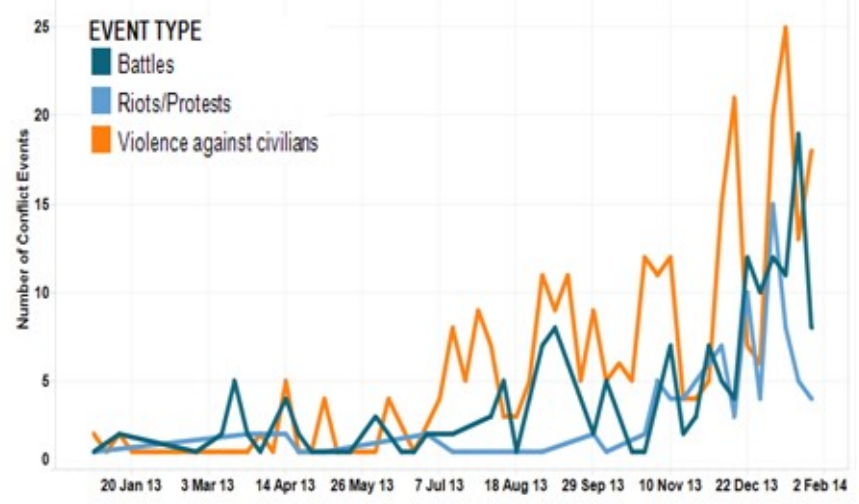

(ACLED, May 2014: Global Conflict Trend, 2014)

Figure 4 shows conflict trend and dynamics in the Central African Republic. March 2013 recorded much of violent conflict, much prevalence of violent conflict against civilians was recorded in April and since then it has been on a steady rise. From March up till July there was least case of riot and more cases were recorded from November up to its peak in December 2013 and January 2014. Violent conflict had been on a steady rise to its peak through August and December 2013 up to February 2014. Violence against civilians has also grown in the same proportion through that period up to its peak in December 2013 and January 2014.
Fig. 4: Conflict Events by Actor and Conflict Type, Central African Republic, December 2013 - January 2014.

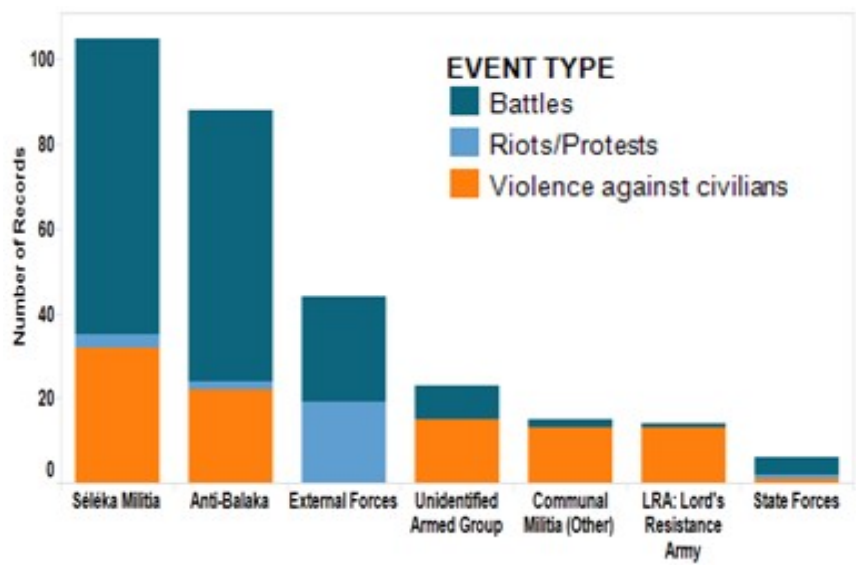

(Heidelberg Conflict Barometer, 2014: ACLED, February, 20014).

Figure 5 depicts the level of each actor's involvement in the violent conflict and the type of conflict carried out by the actors. It can be observed form the figure that $60 \%$ of the violence and killings is carried out by the Seleka rebels. The level of violence carried out by the Anti-balaka militias is also relatively higher close to that of the Seleka rebels, with $10 \%$ lower violence compares to that of the Seleka forces. External forces are involved in both riot and violence in an equal proportion. However, much of violence against the civilians is carried out by an unidentified group, Communal Militias (other) and the Lord's Resistance Army (LRA) carried out violence against civilians in almost an equal proportion. The State Forces were least relatively involved in the battle.

Fig. 5: Troops Deployment, Central African Republic 2013 - 2014

\begin{tabular}{|c|c|c|c|}
\hline Mission & Period & $\begin{array}{c}\text { Authoriza } \\
\text { tion }\end{array}$ & Deployment \\
\hline $\begin{array}{c}\text { Mission for } \\
\text { the } \\
\begin{array}{c}\text { Stabilization } \\
\text { of CA R }\end{array}\end{array}$ & $\begin{array}{c}\text { Dec. 2013 - } \\
\text { Sept. 2014 }\end{array}$ & $\begin{array}{c}\text { UN } \\
\text { Authorize } \\
\text { d Mission }\end{array}$ & $\begin{array}{c}6,000 \text { MISCA } \\
\text { forces backed by } \\
2,000 \text { French } \\
\text { Troops }\end{array}$ \\
\hline $\begin{array}{c}\text { Multidimensi } \\
\text { onal } \\
\text { Integrated } \\
\begin{array}{c}\text { Stabilization } \\
\text { Mission in the } \\
\text { CAR }\end{array}\end{array}$ & $\begin{array}{c}\text { Sept. 2014 - } \\
\text { Date }\end{array}$ & MN & $\begin{array}{c}12,000 \text { UN } \\
\text { Forces } \\
\text { (MINUSCA) }\end{array}$ \\
\hline
\end{tabular}

(African Security Brief ASB, no. 25 July 2013: Congressional Research Services, 2014)

UN Security Council on December 5, 2013 authorized the deployment of 8,000 troops under Resolution 2127 for French supported African led Stabilization Mission in the CAR (MISCA). The challenge of inadequacies had prompted the Security Council to pass Resolution 2149 on April 10, 2014 to deploy 12,000 troops of Multidimensional Integrated Stabilization Mission in the CAR (MINUSCA), taking effect from September 15, 2014, which absorbed the (MISCA) forces. 
Fig. 6: Central African Republic - Fatality by Region/Year

\section{Fatalities each year}

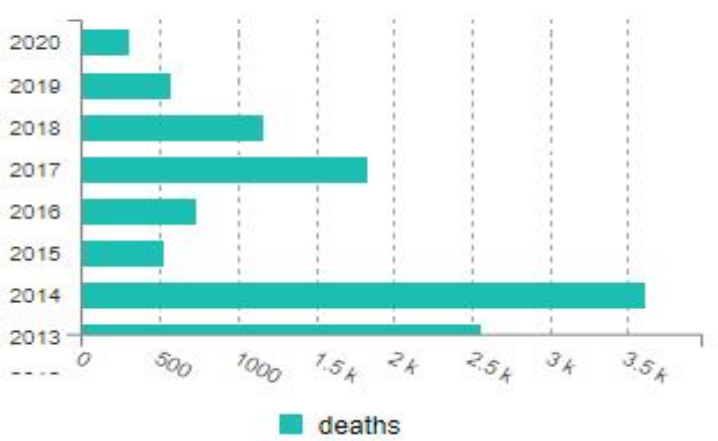

Fatalities per region in latest year

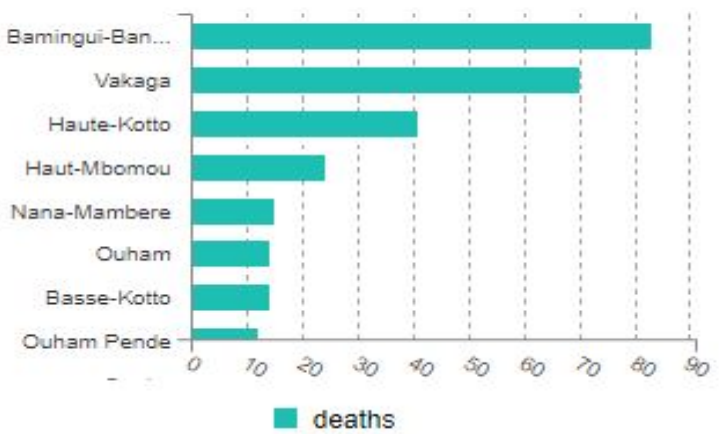

HDX (November 2020) Central African Republic - Conflict Data

Fig. 7: Central African Republic: The Rise of Political Militia

\section{Central African Republic: The Rise of Political Militias}

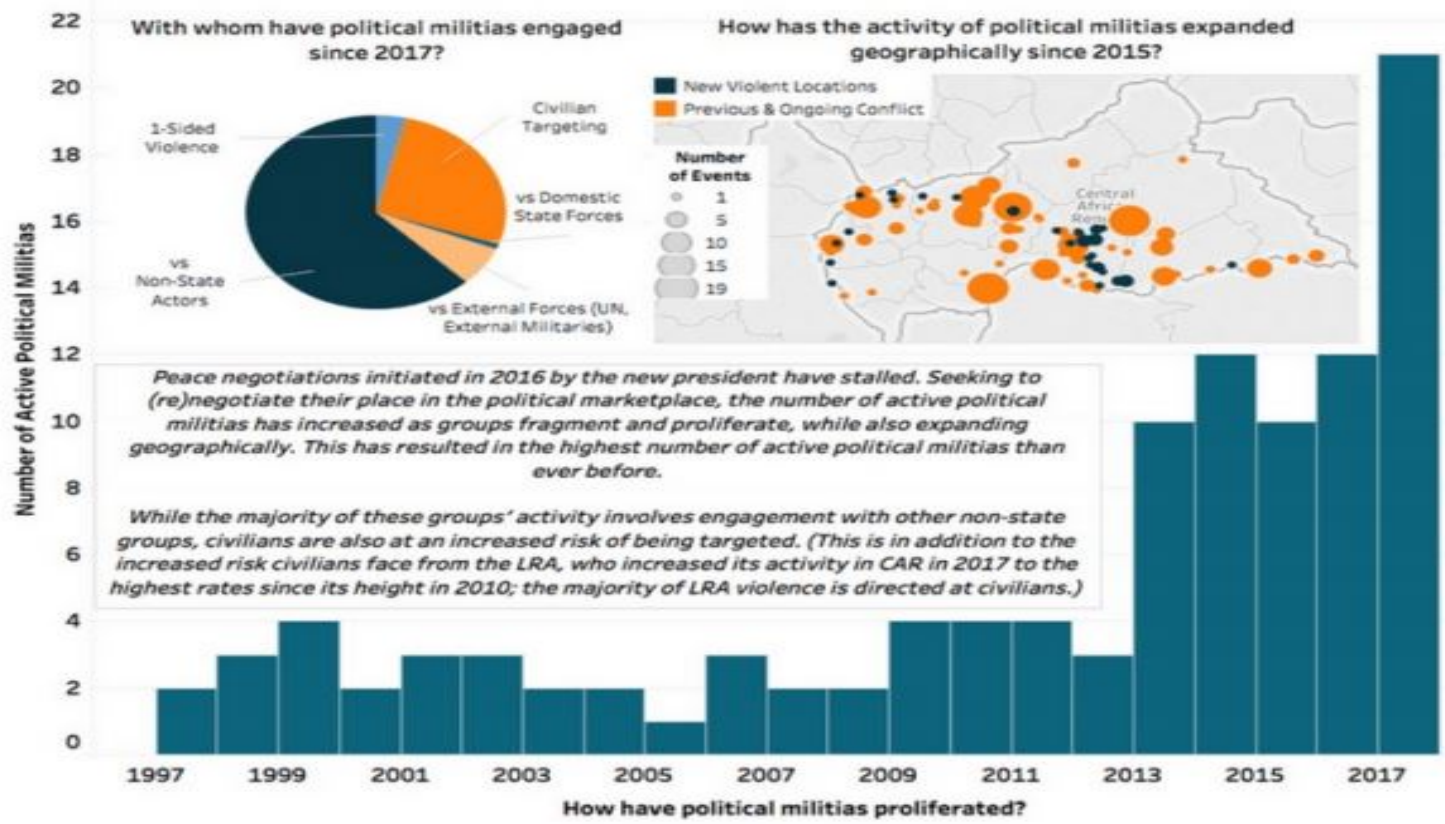

(ACLED February 2018)

\subsection{Summary of Major Findings}

Central African Republic matters to the international community only to the extent that its internal problems affect the stability of the region. In turn, CAR's position in the eyes of the international community shapes the extent, effectiveness and relevance of its response to peaks of violence in the country. Specifically:International actors predominantly share a pessimistic view of CAR, coupled with a general lack of interest in and misunderstanding of the country's internal dynamics. This perception shapes the type of engagement privileged by the international community in
CAR, which is mainly reactive in nature and designed to simply stabilize the country for the sake of regional affairs that are deemed to be of greater importance.

1. Increasing the number of troops significantly decreases violence against civilians by both governments and rebels. Statistical analyses suggest that battlefield deaths decrease when the number of troops deployed increases.8,000 French and African forces deployment of December 5, 2013 was found inadequate by the UN Security Council which prompted the deployment of 12,000 UN Multidimensional Integrated forces 
(MUNISCA) to take over on September 15, 2014, which was subsequently confirmed by the significant decrease in fatality rate as more effective.

2. This study had observed that peacekeepers have had a tendency to adopt a top-down approach to local problems and only consider top-down solutions for those problems. Attempts to understand the localnature of conflicts, and serious efforts to resolve these conflicts through localmechanisms appear to be sparse. This is for the fact that peacekeepers often isolate themselves from local populations to form expatriate communities. The boundaries that emerge hinder a complete understanding of the situation.

3. Conflict in the CAR is complex, involving number of actors; Seleka, Anti-balaka, Communal Violent Actors, Militias, Foreign Assistance, Lord's Resistance Army (LRA), National Forces and Former Rebel Groups with varying degree of involvement in different violence. The shifting dynamics of the CAR Conflict is; since the upsurge, low violence and fewer fatality was recorded, then escalation and increased fatality, and deescalation and decrease in fatality, further re-escalation and future uncertainty. Also, violence against unarmed civilians, violent clashes between warring parties, attacks and reprisals, violence against humanitarian workers, military brutality against the civilians and riots were recorded.

4. Peacekeeping troops had made some impact in the facilitation of humanitarian access, civilian protections in major cities, disarmament and de-escalation. But the peacekeeping mission had been found wanting for selective disarmament and protection, implicated in sexual crimes, brutality against the civilians and indifference.

5. Much of the de-escalation is credited to the Brazzaville Ceasefire Deal of July 23, 2014, facilitated by the National Reconciliation and Political Dialogue led by the Congolese President Denis Sassou Gguesso, but effective state institutions that might contribute to the continued stabilization efforts were absent.

6. UN troop presence has not effectively prevented violence occurrence and is unable to completely protect unarmed civilians from attacks, killings, abductions and forced displacements. Though succeeded in preventing a large-scale massacre in the Central region mid-October, 2014, yet the international forces are stretched thin in part because MINUSCA is still several thousand troops short of its mandated numbers, they have not been able to prevent reescalating violence in the country's central region.

\section{SUMMARY, CONCLUSION AND RECOMMENDATION}

\author{
4.1 Summary \\ Despite the International peacekeeping operations \\ 'unconstrained involvement in the CAR crisis, the fact
}

remains that a bunch of actors with varied interests has arose to confront it. These actors have competed for control over crisis resolution, importance, and discernibility, and have often been driven by key member states, particularly by Chad and France. The delayed transformation of peacekeeping operations not only reflected the strained relations among the various actors, but also hampered an effective international response to the crisis, with fatal results for the CAR's citizens. The number of casualties increased particularly sharply during the MICOPAX/MISCA transformation. No thoughtfully planned peace operation, active long enough to have an enduring impact on the security situation in the CAR, has been established thus far. Much depends now on the ability and willingness of the UN, which has taken the lead and pushed the AU and the ECCAS into the background, to streamline international efforts and engage in sustainable postconflict reconstruction, including the construction of a viable state with functioning security organs and a reconciliation between Muslim and Christian communities. The UN must now walk the tightrope of quickly deploying a well-planned and well-executed mission to satisfy the needs of the CAR, while simultaneously accommodating the demands and interests of the AU and the ECCAS, and allaying the concerns of Chad, France, and other stakeholders (Welz, 2014).

\subsection{Conclusion}

Much of the thoughtful analysis of the current conflict in the Central African Republic (CAR) is now coming to the conclusion that religion was not a dominant motivation in its inception. However, in a country where the "battle lines" have in some places become sharply drawn between the primarily Muslim Seleka and the primarily Christian anti-balaka, it is instructive to find out how such a situation has arisen.

CAR, a war that began for economic and political reasons has been recast through the need for strong bases of support and the desire for self-defence and revenge, into a conflict where religion now seems to be an obstacle in the search for peace.

Professor Robert Bates of the Department of Government at Harvard University says generally the main reason for broadening the definition of a conflict to a religious battle is to gain potential coalitional partners. This theory would correspond with the Hoex's suggestion that the Seleka may have primarily killed Christians at the start of the conflict in order to build a more organised and clearly defined base in their heartlands. Yet the Seleka have looked for non-Muslim recruits in Bangui, and the anti-balaka claimed its recent violence in Bangui was an attempt to force the resignation of president Catherine Samba-Panza, who is herself a Christian, suggesting the conflict for the anti-balaka leaders at least is a political rather than religious one.

The truth, then, as to why the conflict has become more religiously based as it has proceeded, may be more to do with the subconscious of individual CAR citizens and less to do with overarching goals of the "political groups". Scott Bollens, Professor and Warmington Chair of Peace and 
International Cooperation at the University of California says people and groups facing "existential threat" naturally seek "identifiers" as a means of maintaining, revitalising, and reinventing a sense of who they are.

"Religion and sect are potent and compelling identifiers, providing narratives of struggle, righteousness, and martyrdom that have great appeal," Bollens says. Although religious identifiers are generally applied by leaders to radicalise constituents during a conflict along an "us versus them" mentality, in the case of the CAR, with the state falling away and both set of protagonists having only lose control over their members, it seems this has been a bottom-up mentality born of a need for identity and kinship in a country that has fallen apart.

\subsection{Recommendations}

1. The dominant reactive nature of engagement in CAR produces an unsuccessful response that comes to the detriment of long - term development projects, needed to reach an effective conflict prevention approach. A combination of both strategies (short-term and long term) could help avoid the routine reoccurrence of conflict.

2. The government of CAR required international support for high-level discussions and mediation to develop systems regulates and manages mining and forestry. The principles of transparency, accountability, inclusivity and equityneed to guide (1) the issuance, implementation, and enforcement of concessions and (2) the collection and management of resource revenues. CAR should work towards reinstatement as a member of both the Kimberley Process and the Extractives industries Transparency Initiative (EITI) and to expand EITI to include the timber industry and possibly other high-value resources. The Government of CAR and Multilateral Development Banks

3. Implement a transition-oriented negotiation to articulate and map out the development of transparent, equitable legal frameworks and institutions responsible for the management of high-value natural resources. Ensure that all conflict assessments for CAR include analyses of the role of natural resources in the conflict and recovery, including an assessment of existing mechanisms for revenue management and benefit sharing for diamonds, gold, timber and possibly agricultural cash crops. Assessments may also need to consider the potential effects of the development of uranium and hydrocarbon deposits through future concessions. This would address a critical gap in the current management of natural resources and could be used to launch a national dialogue on the management of such revenues.

4. The international community should assist CAR in identifying options for reforming the laws governing revenue management and benefit sharing. This include adding clear procedures for maintaining local and national government accountability for how revenues are spent.

5. International community should support the establishment of a legal framework to allow for transparent benefit sharing with producing communities. This included the redeployment of local administrative institutional capacity in accordance with the UN Peacebuilding Commission's priorities in CAR and based on in-depth stakeholder consultations with producing communities. The creation of checks and balances was be needed to ensure that natural resource revenues provide measurable benefits at the local level.

\section{REFERENCES}

[1] Annan, K. (1999) Peacekeeping Military Intervention and National Sovereignty in Internal Armed Conflict, Oxford

[2] (1999) Criteria for Humanitarian Intervention - Online News Hours, $18^{\text {th }}$ October $1999-$ available at www.onlinenewshours.com - accessed 09/04/2014

[3] Arieff, A. (2014) Crisis in the Central African Republic, Congressional Research Service - available on www.crs.org accessed 09/04/2014

[4] Azar, E. (1990) The Management of Protracted Social Conflict: Theory and Cases, Aldershort, Dartmouth.

[5] ACLED (2013) Conflict Trends: Real-Time Analyses of African Political Violence, Armed Conflict Location and Data Base available at www.starusscentre.org - accessed 8/5/2014

[6] (2014) Armed Conflict Location, Event and Data Project Conflict Trends (No. 26) Real-Time Analysis of African Political Violence, May 2014

[7] (2014) Armed Conflict Location and Dataset, Conflict Trends (No. 23) Real-Time Analysis of African Political Violence, February 2014

[8] (2014) Armed Conflict Location and Dataset, Conflict $\overline{\text { Trends }}$ No. 27) Real-Time Analysis of African Political Violence, June 2014

[9] (2015) Armed Conflict Location and Dataset, Conflict Trends (No. 27) Real-Time Analysis of African Political Violence, September 2014

[10] (2018) The Rise of Political Militias in the Central African Republic, $\quad$ February 2018 https://acleddata.com/?s=central+africa

[11] All Africa (2014) CAR Warring Parties Reached Cease Fire Deal - available at www.allafrica.com - accessed 20/09/2014

[12] Amnesty International (2013) Central African Republic: Human Rights Crisis Spiraling Out of Control - available at www.theguardian.com - accessed 10/04/2014

[13] (2014) UN Credibility at StakeAmid Rising Attacks Against Civilians - available at www.amnesty.org accessed 07/11/2014

[14] (2014) CAR: Urgent Action Needed to Tackle Escalating Violence in the Central region - available at www.amnesty.org - accessed 07/11/2014

[15] APA News Agency (2014) Brazzaville Forum Reaches Cease Fire Agreement on CAR - APA news July 24, 2014 available at en.starafrica.com - accessed 20/09/2014

[16] ASB (2013) Peace Operations in Africa: Lesson Learned Since 2000 - African Security Brief no. 25 July 2013 - A Publication of the African Centre for Strategic Studies

[17] AU (2013) Operationalisation of Rapid Deployment Capacity of the African Standby Force - available at www.au.org/doc/rpt/exp accessed 222/10/2014

[18] Bartos, O. J. and Wehr, P. (2002) Using Conflict Theory, Cambridge University Press

[19] Baumann et al., (2013) Strategic Trends: Key Developments, Global Affairs, Centre for Security Studies, Zurich. 
[20] BBC (2014) Central African Republic Humanitarian Crisis Gettingout of Control, 17 January - available at www.bbc.com/car - accessed 10/04/2014

[21] BBC (2018) Central African Republic Country Profile, $1^{\text {st }}$ August 2018https://www.bbc.com/news/world-africa-13150040

[22] Bellamy, A.J. and Wheeler, N.J. (2005) Humanitarian Intervention in World Politics, Oxford University Press.

[23] Better World Campaign, (2014) Crisis in the Central African Republic: Navigating the U.S Response.

[24] Bontwell, J. and Klare, M. (2000) A Scourge of Small Arms, Cambridge, American Academy of Arts and Sciences.

[25] Brinkman, H. J. et al. (2013) Addressing Inequality as Horizontal Drivers of Conflict in the Post-2015 Development Agenda, Saferworld.

[26] Brownlie, I. (1996) Principles of Public International Law, Oxford, Oxford University Press.

[27] Buzan, B. (1991) People, State and Fear, Boulder, Lynne Rienner.

[28] Buzan, B., et al. (1998) Security: A New Framework for Analysis, Boulder, Lynne Rienner.

[29] Cederman, L. E. et al. (2013) Inequality, Grievances and Civil War, Cambridge University Press.

[30] CIA World Factbook (2014) Demographic Information on CAR Rough Estimations - available at www.cia.org/factbook - accessed $19 / 09 / 14$

[31] Cilliers, J. (2000) Resource Wars: A New Type of Insurgency, Institute of Security Studies (ISS) Working Paper - available at www.iss.org/resourcewars - accessed 19/09/14

[32] (2011) African Future 2050: ISS Monographs 175: Institute of Security Studies, Pretoria - available at www.issafrica.org/pgcontent -accessed 20/09/2014

[33] Cocodia, J. (2008) Exhuming Trends in Ethnic Conflict and Cooperation in Africa: Some Selected State, African Journal of on Conflict Resolution, Vol. 8 no. 3

[34] Collier, P. (2012) The Benefit in Reducing the Incidence of Civil War - available at www.users.ox.ac.uk/econpro/research/conflict accessed 22/10/2014

[35] Coning, C. et al. (2008) UN Peacekeeping Operations, NUPI, Oslo

[36] Council for Foreign Relations (2020) Global Conflict Tracker, https://www.cfr.org/global-conflict-tracker/conflict/violencecentral-african-republic

[37] DFID (2009) Building the State and Security, the Peace Department for International Development, London.

[38] Dowell, A. (2010) International Community and Intervention in Cases of Genocide, Leeds University Press.

[39] Dowty and Loescher (1996) Refugee Flows as Ground for International Action, International Security, Vol. 21, No. 1

[40] Crossman, A. (2011) Conflict Theory: An OverviewCentre for Humanitarian Dialogue (2016) Mediation and Support for The Peace Process In The Central African Republic

[41] Enuka, C. (2012) Post-Cold War Conflict: Imperative for Armed Humanitarian Intervention, Global Journal of Human Social Science, Vol. 12 No. 9

[42] Ero, C. (2014) Why Has the International Community Failed to Prevent State Fragility? Available at www.ssp.ceu.hu/article accessed on $05 / 05 / 2014$

[43] Francis, D. (2000) The Fire Next Door: Regional Diplomacy and Conflict Resolution in West Africa, African Review of Foreign policy, Vol. 2 No. 2

[44] Fortna, V.P (2008) Does Peace Operations Works? Shaping Belligerents Choices after Civil War, Princeton University Press

[45] Galtung, J. (1995) "Conflict Resolution as Conflict Transformation: The First Law of Thermodynamics Revisited." In Kumar Rupesinghe, ed., Conflict Transformation, New York: St. Martin's Press

[46] Geneva Declaration (2011) Global Burden of Armed Violence, Lethal Encounters: Cambridge University Press

[47] (2011) Geneva Declaration Leaflet - available at www.genevadeclaration.org/fileadmin - accessed 20/09/14

[48] George, A. and Keohane, R. (1980) The Concept of National Interest: Uses and Limitations, Westview Press, Colorado.
[49] Global Conflict Trend (2013) The Poorer Countries and Security available at www.systemicpeace.org/conflict - accessed 20/09/14

[50] Goldstein, J. (2008) International Relations, International edition, Pavehouse

[51] Goldstone, et al. (2011) A Global Model for Forecasting Political instability, International Affairs 32(2)

[52] GSDRC, (2014) The Causes of Conflict (Part I and II), University of Birmingham - available at www.gsdrc.org/conflict accessed on $13 / 08 / 14$

[53] Gurr, T. and Barbara H. (1994) Ethnic Conflict in World Politics. Boulder, CO: Westview Press.

[54] Guraziu, R. (2008) Is Humanitarian Military Intervention in the Affairs of Another State Justified? Global Security, Middlesex University Press.

[55] HDX (2020) Central African Republic - Conflict Data- November 2020https://data.humdata.org/dataset/acled-data-for-centralafrican-republic

[56] Heidelberg Conflict Barometer (2011) World Conflict Data available at www.hiik.de/conflictbarometer - accessed 19/09/14

[57] Henderson, E.A. (2002) When States Implode Africa's Civil Wars 1950-1992 World Affairs 161

[58] Henquinet, M. (2014) International Forces Fail to Stem killings in the CAR - available on www.globaljournalist.com - accessed $07 / 05 / 2014$

[59] Holzgrefe, J.L. and Keohane, R. (2003) Humanitarian Intervention: Ethical, Legal, and Political Dilemmas, Cambridge University Press.

[60] Huntington, S.P. (1999) The Lonely Superpower, Foreign Affairs, Vol. 78, No. 2

[61] Human Right Watch (2013) Reports on the Situation in the Central African Republic - available at www.hrw.org/car - accessed 19/09/14

[62] International Crisis group (2013) Policy Briefing: Central African Republic: Better Late than Never - available at www.icg.org/car accessed 19/09/14

[63] Ira, K. (2013) French War in Central African Republic Intensifies Humanitarian Crisis - available on www.globalresearch.ca accessed - 10/04/2014

[64] ISS (2013) The Future of Intra-state Conflict in Africa: More Violence or Greater peace? Institute of Security Studies Working Paper - available at www.iss.org/africanconflict - accessed $17 / 08 / 2014$

[65] Jacobson, B. (2005) Beyond Security, New Approach, New Perspectives, New Actors - available at www.russfound.org/consult - accessed on 15/04/2014

[66] James, D. et al. (2003) Ethnicity, Insurgency and Civil War, American Political Review 97(1)

[67] Jervis, R. and Snyder, J. eds. (1991) Dominoes and Bandwagons: Strategic Beliefs and Great Power Competition, Oxford University Press.

[68] Johnson, P. (1993) Intervention and Moral Dilemmas, Macmillan Press, Houndmills.

[69] Jones, B. et al. (2009) Building on Brahimi: Peacekeeping in an Era of Strategic Uncertainty, New York Center on International Cooperation

[70] Kaldor, M. (2001) New and Old Wars, Polity Press, Cambridge

[71] Kanbur, R. (2007) Poverty and Conflict: the Inequality Link, International Peace Academy, New York.

[72] Kegley, C.W. et al. (2011) World Politics, Trends and Transformations, Wadsworth, Boston.

[73] Kithure, K. (2001) The Application of Humanitarian Intervention to Internal Armed Conflict in Africa: East African Journal of Peace and Human Right, Vol. 7 pp. 29.

[74] Le Billion, P. (2003) Buying Peace or Fuelling War: The Role of Corruption in Armed Conflicts, Journal of International Development Vol. 15 no. 4

[75] Lederach, J. P. (2000) Conflict Transformation: A Working Definition." In Carolyn Schrock-Shenk, ed., Mediation and Facilitation Training Manual Akron: Mennonite Conciliation Service 
[76] Marchal, R. (2013) Central African Republic: Back to War Again, Global Observatory.

[77] Mashishi, A.K. (2003) Intervention in Africa: Assessing the Rational Behind Sub-Regional Peacemaking Military Intervention, Monterey, California.

[78] Mazrui, A. A. (2001) Conflict in Africa: An Overview - available at www.ohioswallow.com - accessed on 08/05/2014

[79] Monty, G. et al. (2001) Conflict, Governance and State Fragility, Centre for Systemic Peace.

[80] Mortimer, R. A. (1996) Islamists, Soldiers and Democrats: The Second Algerian War, Middle East Journal Vol. 5.

[81] Nyakanvzi, E. (1998) Genocide: Rwanda and Burundi. Rochester, VT: Schenkman Books.

[82] O'Hanlon, M. (1996) Saving Lives with Force: Military Criteria for Humanitarian Intervention, Brookings Institution, Washington, DC.

[83] Orellana, S.A. (2009) Ethnic-Religious Conflicts: Exploring the Role of Religion in Conflict Resolution, SAGE, London.

[84] Oyeniyi, A. (2011) Conflict and Violence in Africa: Causes, Solutions, Sources and types - available at www.transcend.com accessed 12/05/2014

[85] Perlman, W. et al. (2012) Non State Actors, Fragmentation and Conflict Processes, Journal of Conflict Resolution 56(1)

[86] Pew Research (2010) Tolerance and Tension: Islam and Christianity in sub-Saharan Africa - available at www.pewresearch.org/pubs - accessed 20/09/14

[87] Raimo, V. (1991)To Settle or to Transform? Perspectives on the Resolution of National and International Conflicts. In Raimo Vayrynen, ed., New Directions in Conflict Theory: Conflict Resolution and Conflict Transformation. London: Sage.

[88] (1991) New Directions in Conflict Theory: Conflict Resolution and Conflict Transformation. International Science Council, London: Sage

[89] Rice, S.E (2009) Prepared remarks before the UN Security Council Debate on Peacekeeping, New York, June 29, 2009 available at www.usun.state.gov/briefingstatement - accessed $22 / 10 / 2014$

[90] Rovera, D. (2014) Central African Republic Intervention is Incompetent, Guardian Africa Network, $10^{\text {th }}$ March, 2014 available at www.theguardian.com/worldnews/car - accessed $10 / 04 / 2014$

[91] Sen, A. (2008) Violence, Identity and Poverty, Journal of Peace Research, Vol. 45

[92] Seybolt, T.B (2007) Humanitarian Military Intervention: The Condition for Success and Failure, Oxford University Press.

[93] (2009) Controversies about Humanitarian Military Intervention, Oxford University Press.

[94] Smith, M. (2003) Guerrillas in the Mist: Reassessing Strategy and low Intensity Warfare, Review of International Studies, Vol. 29 No. 1

[95] Stedman, J.S (1997) Spoiler problem in Peace Process, International security 22 no.9Stiglitz, E. and Kaldor, M. (2013) The Quest for Security: Protection without Protectionism and the Challenges of Global Governance, Cambridge

[96] Stewart, F. (2002) Root Causes of Violent Conflict in Developing Countries: Causes to Prevention - available at www.bjm.com/content - accessed 12/05/2014

[97] Stewart, F. et al. (2008) Major Findings and Conclusions on the Relationship Between Horizontal Inequalities and Conflict, Palgrave Macmillan.

[98] Straus, S. (2009) Rebels without Borders: Transnational Insurgencies in World Politics, New York: Cornell University Press.
[99] (2012) Wars Do End: Changing Patterns of Political Violence in sub-Saharan Africa, African Affairs 111(443

[100] Terry, F. (2002) Condemned to Repeat: Paradox of Humanitarian Action, Cornel University Press

[101] Teson, R (2003) The Liberal Case for Humanitarian Intervention, Cambridge University Press.

[102] Times (2016) How to Stabilize the Central African Republic, $5^{\text {th }}$ April 2016

[103] UCDP (2012) Uppsala Conflict Data Program - available at www.ucdp.uu.se/database - accessed 19/09/14

[104] UN (2004) A More Secure World: Our Shared Responsibility, Report of High Level Panel on Threat, Challenges and Change available at www.un.org/en/sec - accessed 8/5/14

[105] UN, (2008)a UN Peacekeeping Operations: Capstone Doctrine Report, Oslo Doctrine Seminar 14 \& 15 May 2008, Oslo, Norway - available at www.nupi.no/capstonedoc - accessed 11/08/2014

[106] UN (2008)b UN Peacekeeping Operations: Principles and Guidelines - available at www.un.org/operationsguides - accessed $22 / 10 / 2014$

[107] UN (2011) Secretary General's Remark at Security Council Debate on Peacekeeping - UN August 26, 2011 - available at www.un.org/statements- accessed 22/10/2014

[108] UN (2014) Report of the Secretary-General on the Central African Republic, March 3, 2014, U.N. doc. S/2014/142

[109] UN News Service (2014) WFP Chief Declares 'The Time Is Now' for Central African Republic, April 11, 2014 - available at www.unnewsservice.org/car - accessed 19/09/14

[110] UNIP (2019) Central African Republic President on 'Path to Peace, April 2019 CAR's eighth peace deal stands best chance yet of ending years of internal strife, Faustin-Archange Touadera says.

[111] UNOCHA (2014) U.N. Office for the Coordination of Humanitarian Affairs Estimates CAR's Population at 4.6 million.

[112] UN News (2016) Central African Republic has 'turned its back on past dark dayshttps://www.un.org/africarenewal/africaga2016/news/centralafrican-republic

[113] USAID (2014) Central African Republic, Humanitarian Update, January 13 - available at www.usaid.gov/responsiblity - accessed $05 / 05 / 2014$

[114] (2013) Peace Operations in Africa: Lessons Learned, African Centre for Strategic Studies - available at www.africancentre.org/papers accessed on 22/10/2014

[115] Walzer, M. (2000) Just and Unjust Wars: A Moral Argument with Historical Illusions, Basic Books, New York.

[116] WDR (2011) Conflict, Security and Development: World Development Report, available at www.wb.org/wdr2011 accessed 19/09/14

[117] Welz, M. (2014) African Affairs Volume 113, Issue 453, October 2014, Pages 601-610

[118] Weiss, T. and Chopra, J. (1995) Beyond Westphalia, John Hopkins University Press

[119] Weiss, T. G. (2004), The Sunset of Humanitarian Intervention? The Responsibility to Protect in a Unipolar Era, Security Dialogue, $35(2)$

[120] William, D. (2013) Peace operations in Africa Lessons Learned Since 2000: African Security Brief, African Center for Strategic Studies.

[121] Wyk, J. A. (2007) Political Leaders in Africa: Presidents, Patrons or Profiteers? Occasional Paper Series, Vol. 20. No. 1, the African Center for the Constructive Resolution of Disputes (ACCORD), South Africa.

[122] Zeleza, P.T (2010) Causes and Costs of War in Africa: Liberation Struggle to War on Terror - available at www.ohioswallow.com/extra - accessed12/05/2014 